\title{
Siret river basin planning (Romania) and the role of wetlands in diminishing the floods
}

\author{
G. Romanescu \\ "Alexandru Ioan Cuza" University of Iasi, Romania
}

\begin{abstract}
The Siret river flows from the wooded Carpathians (Ukraine) and on the Romanian territory it has a length of $559 \mathrm{~km}$, from its entrance into the country till its mouth into the Danube. Practically, it is the river basin with the highest hydro-energetic potential and with the greatest fresh water supply in Romania. The total theoretical water resource in the Siret river space represents 6,868 million $\mathrm{m}^{3} /$ year, which is above the average for Romania. In order to ensure the water sources for different use and to diminish the high floods which are more numerous and stronger, 31 accumulations have been built, with a volume exceeding 1,206.12 mln. $\mathrm{m}^{3}$. In 2005 the Siret recorded a historical flow with values between $5,000-5,500 \mathrm{~m}^{3} / \mathrm{s}$, representing the highest flow on the interior rivers in Romania. Unfortunately, in the last 50 years, a great part of the large wetlands in this river basin have been drained, changing their destination and therefore, changing their role in diminishing floods, in recharging the aquifers and in representing a habitat for different species. In order to protect the human settlements in different regions, $570.2 \mathrm{~km}$ of rivers undertook regulation actions and $357.7 \mathrm{~km}$ of dams were built. Due to the torrential character of most of the rivers in the Siret basin, water consumption appeared and developed from simple water use to the great complex accumulations. In reality, the great reservoirs and the preserved wetlands along the main course or along other tributaries have diminished a part of the high floods produced in the last years.
\end{abstract}

Keywords: hydro-technical facilities, river basin, floods, wetlands.

\section{Introduction}

The Siret river basin is the most important fresh water supply in Romania and it also represents the most complicated water course network. 


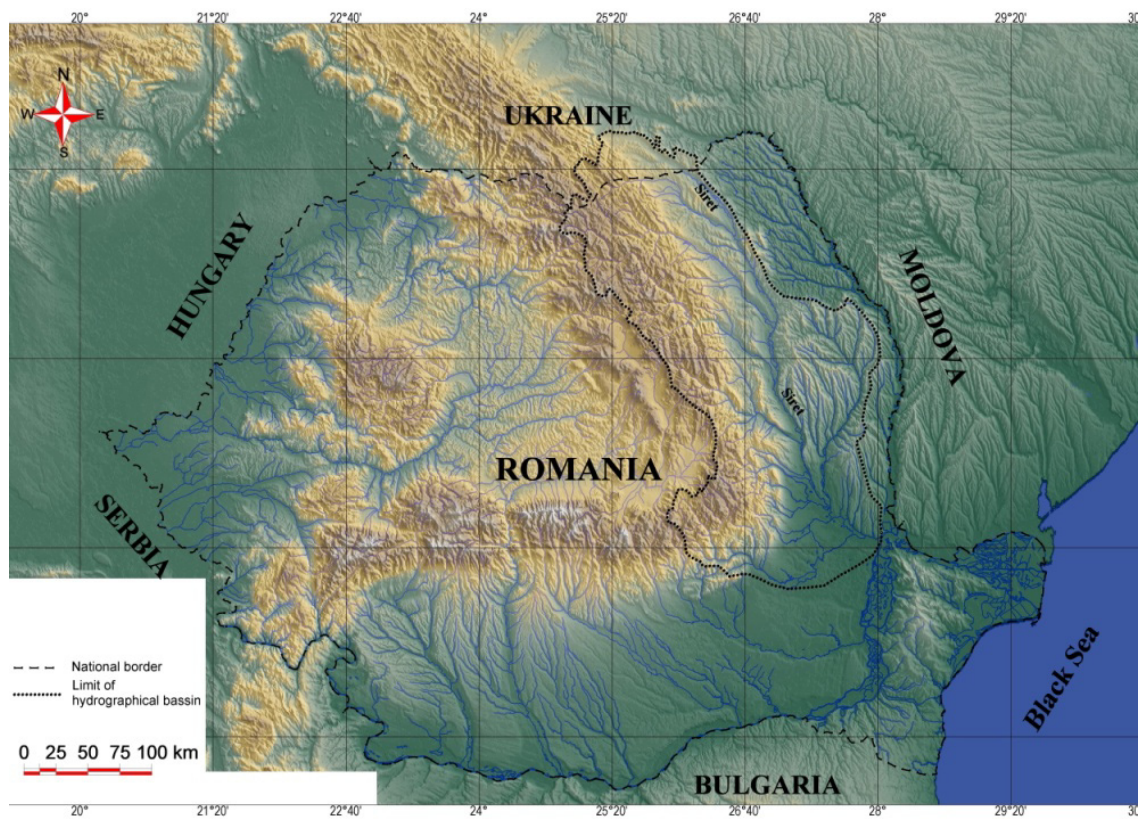

Figure 1: The geographical position of Siret river basin on the territory of Romania.

As the tributaries of the Siret come from two totally different landforms (the Carpathians, to the west and the Moldavian Plateau, to the east) the character of the discharge is also differentiated (fig. 1). The complexity of the discharge is amplified by the unequal development of the river basin: the greatest part in the west (mountain area) and the smallest part in the east (the hilly area).

In the present paper, three main characteristics of this great river basin are mentioned: the torrential character (more obvious in the last years); the importance of the hydro-technical works over the whole river basin (the Romanian Territory); the role of the wetlands in diminishing the high floods.

The torrential character of the rivers in the Siret river basin can be amplified by the human interventions in the last years, especially by the massive deforestation in the Carpathians. The arguments for this statement are connected to the intensity of floods in the small river basins, severely deforested and highly populated. At the same time, the connection between the frequency and intensity of floods and the economic development of the populated areas in the Siret river basin is analysed.

Knowing the torrential character of the main tributaries, many hydrotechnical works were built starting the 19th century, in order to stop or diminish the high floods, especially in the areas with high human densities. Most of the planning projects have as their main goal a total protection. Were these measures enough? Which are the main factors in generating the historical floods in the last years? What is the human contribution and what is the state role in protecting the 
populated areas? Preserving the wetlands is a protection measure or just a caprice of the ecologist movements?

\section{Regional setting}

The Siret river flows from the wooded Carpathians (Ukraine) and on the Romanian territory it has a length of $559 \mathrm{~km}$, from its entrance into the country till its flow into the Danube. The upper course develops on the Ukraine territory, the middle course crosses the Suceava Tableland, and then the limit between the Moldavian Sub-Carpathians and the Bârlad Tableland, and the lower course crosses the Inferior Siret Plain. The hydrographical network includes 1,013 water courses (the richest in Romania) and measures $15,157 \mathrm{~km}(19.2 \%$ of the total length of the Romanian network, with a density of $0.35 \mathrm{~km} / \mathrm{km}^{2}$, as compared to $0.33 \mathrm{~km} / \mathrm{km}^{2}$ that is the average for the whole country). This river has the greatest reception basin $\left(44,871 \mathrm{~km}^{2}\right)$, with a total area of $42,890 \mathrm{~km}^{2}$ in Romania (18.1\% of the Romanian territory, or $96.5 \%$ of the surface of the whole river basin). The forests cover a surface of $15,882 \mathrm{~km}^{2}(37 \%$ of the river basin surface and $25 \%$ of the total forest area in Romania).

The Siret Water Headquarters in Bacau administrates $28,678 \mathrm{~km}^{2}(66.8 \%$ of the basin area or $11.9 \%$ of the surface of Romania). The forests within this administration cover a surface of $15,882 \mathrm{~km}^{2}(37 \%$ of the river basin and $25 \%$ of the forest area in Romania) (Atlas of Waters Survey, Romania [1]). Between the river source and the river mouth, there is a difference of $1,236 \mathrm{~m}$. The Siret river basin is typically non-symmetrical as it was formed by the mountain tributaries on the right (the mountain sector). The mathematical coordinates are: $47^{0} 58^{\prime} \mathrm{N}$; $45^{0} 28^{\prime} \mathrm{N} ; 24^{0} 49^{\prime} \mathrm{E} ; 28^{0} 2^{\prime} \mathrm{E}$.

\section{Materials and methods}

In order to realize this study the hydrological data and the data on the hydrological works provided by the Siret Waters Headquarters, Bacau and the Hydrology Institute in Bucharest have been used. For the case study data on the historical water flow in the summer of 2005 have been processed. For most of the accumulations, local information were needed, regarding the date they started to work, the water volume they contain and they engage during one year, their functioning, the ecological parameters etc.

For an accurate evaluation of the most recent and the most important floods, the satellite images provided by the Siret Waters Headquarters, Bacau, the Hydrology Institute in Bucharest, the Romanian Space Agency, or from internet (http://sertit.u-strasbg.fr/) have been analysed.

The satellite images referred mainly to the days when floods occurred and they were interpreted in terms of affected land, surface, engaged water volume etc. For the interpretation and analysis of the territories affected by floods, a series of satellite images taken while the phenomenon was happening, were used. The estimation of the surfaces was made by interpreting the LANDSAT TM 
2003 images, by using FAO-LCCS classification methodology. Data processing was done in ASR-CRUTA remote sensing laboratory, on 19th July 2005, using the images resulted from activating the international CHARTER (Call ID-98).

For the evaluation of the local and regional damages, we have processed the data coming from the commune and town-halls, but at the same time data from the field, from the local people or data resulted from our own observations. The data on the damage caused to the infrastructure, especially roads and railways, were taken from the Ministry of Transport.

In order to point out the effects of the floods and the role of the wetlands, we have analysed and indexed the most important areas, with a key role in controlling the Siret floods. A rich national and international bibliographical and cartographic material was consulted: André et al. [2]; Diaconu [3]; Fustec and Frochot [4]; Gopal et al. [5]; Hauer and Smith [6]; Kentula [7]; Kolva [8]; Mustatea [9]; Romanescu [10, 11]; Romanescu et al. [12, 13]; Romanescu and Romanescu [14]; Skinner and Zalewski [15]; Smith [16]; Selarescu and Podani [17]; Serban and Galie [18]; Vasenciuc [19].

In order to point out the morphological effects on the flood plains, we have done measurements in the field, using Leica station (1997) as well as inquiries in order to evaluate the psychological state of the affected population. The cartographic materials provided by Siret Waters Headquarters - Bacau as well as the physico-geographical maps in which the wetlands in the Siret river basin are represented according to their altitude represented a significant help.

\section{Results}

Siret River's discharge is the highest of all internal rivers of Romania $\left(210 \mathrm{~m}^{3} / \mathrm{s}\right.$ at the river mouth) and this is caused by the fact that most of the tributaries come from the mountain sector (the Eastern Carpathians).

The length of the river network of the Siret river basin is $15,836 \mathrm{~km}$, of which, $15,157 \mathrm{~km}$ is found on the Romania territory and $10,280 \mathrm{~km}$ within the Siret Waters Headquarters Bacau (the average density within this direction is $0.37 \mathrm{~km} / \mathrm{km}^{2}$ ). We have to mention the fact that the drying up phenomenon is manifested on $8.3 \%$ of the length of this river network.

The whole river basin has an N-S general orientation. On the right side, the water courses have a NW-SE orientation. The whole surface of the river basin stretches four great landform units: Eastern Carpathians, Moldavia SubCarpathians, Moldavian Plateau, and Inferior Siret Plain.

The climate in this area is a temperate one, with continental influences. The thermal parameters are situated between the following values: annual average temperature is $4^{\circ} \mathrm{C}$ in the mountain area, $8^{\circ} \mathrm{C}$ in the hilly and plateau area, $10^{\circ} \mathrm{C}$ in the plain area. The annual average amount of precipitation ranges between $1000 \mathrm{~mm} /$ year and $450 \mathrm{~mm} /$ year.

An important characteristic of the Siret river space is represented by the torrential character of the flow, caused by the continental-temperate climate, with increasing excessiveness from west to east. Under such conditions, water 
consumptions appeared and developed from simple use to great complex accumulations.

Administratively, the Siret river space covers the whole Suceava county, almost the whole Neamt, Bacau, Vrancea counties, and part of Buzau, Iasi, Harghita, Covasna, Galati, Bistrita Nasaud, Maramures, Botosani counties. The total population in this area is 2,500,867 inhabitants, of which, 990,379 loc. (39.6 $\%)$ live in the urban areas. Of the total population, $37.4 \%(81.85 \%$ in the urban areas and $8.21 \%$ in the rural area) is connected to the centralized water supply systems and $31.77 \%$ (75.24\% in the urban area and 3.28\% in the rural areas) are connected to the sewage treatment stations. Within the Siret river space there are 343 human settlements, 5 of them exceeding 100,000 inhabitants, 36 exceeding 10,000 inhabitants, 293 between 2,000 0 10,000 inhabitants and 9 under 2,000 inhabitants. 43 of these human settlements have sewage treatment stations while 300 do not have such installations. The population connected to the sewage system represents $66.99 \%$ in the urban area and $0.43 \%$ in the rural area. The population connected to the sewage treatment stations represent $66.198 \%$ in the urban area and $0.45 \%$ in the rural area. In the Bârlad river space (tributary of the Siret to the left), the population connected to the centralized water supply systems represent $45.5 \%$ and those connected to the sewage treatment stations, only $29.8 \%$.

The theoretical total water resource in the Siret river space represents $6,868 \mathrm{~m}^{3} /$ year and the specific resource represents $2,746 \mathrm{~m}^{3} /$ inhabitants /year, and this represents more than the average value for the whole country. In order to assure the water supply for different uses, 31 important reservoirs have been created, with a useful volume of $1,206.12$ million $\mathrm{m}^{3} .14$ surface water catchments have been identified and $78.9 \%$ of them have a protection area, and 84 underground water catchments, of which $98.8 \%$ have protection areas (Siret Waters Headquarters, Bacau [20]).

As a result of the economic development in the period 1960-1989 (the year of the Democratic Revolution in Romania), the water quality got much worse as compared to the reference state in the 50's. Starting with 1989, the state of water quality improved due to the diminution of the economic and social activities as well as to the application of the economic mechanism in the field of waters, including the ,those who pollute will pay” principle.

The hydro-morphologic pressures affect 48 rivers, of the total 695 water courses in the Siret geographic space. The most important hydro-morphologic pressures are caused by: 31 reservoirs, the most important being Izvorul Muntelui on the Bicaz, with an area of 3,120 ha; $357.7 \mathrm{~km}$ dams and $570.2 \mathrm{~km}$ regularizations, the most important being on the rivers Canepiste $(100 \%$ of its length), Horodnic (75\%), Dragomirna (82\%), Salcea (90\%), Pozen (58\%), Saca $(59 \%)$, Breaza $(71 \%)$; 4 water deviations; 3 water plugs and 24 important restitutions.

Representative for the Siret river space are also the hydro-technical water planning works realized in cascade, constituting, at the same time, significant hydro-morphological pressures along the Bistrita and Siret rivers. 
In the last 50 years, a large part if the wetlands situated along the rivers, have changed their destination due to the dams. Unfortunately, these zones have lost their protection role against high floods, the role of recharging the aquifer and habitat for different plant and animal species. The total length of the rivers which will have sectors for aquatic species protection, until 2010 , will be about $12.62 \%$ of the total length of the water courses. The areas destined to the aquatic habitat protection cover 102,302.48ha.

The most devastating hydrologic phenomena occurring in the Siret river basin are represented by floods, with catastrophic effect in many cases. In the present case, only the certain data will be considered, regarding the floods in the Siret river basin, and especially the historical flow recorded in 2005.

Due to the existence of a thick snow cover and of a rainy season in March, in the spring of 1932, floods were registered, and they affected the greatest part of Romania. That year, during the high floods, the highest known levels were exceeded in the case of 70 hydrometric stations (out of the 229 existent one) (Mustatea [19]).

The maximum level of $410 \mathrm{~cm}$ was registered at Barbos, on the Siret.

In 1970, catastrophic high floods were recorded on all water courses in Romania. On the rivers in Moldova, the maximum recorded flow was higher than the rest of the years. The floods were caused by high amounts of precipitation falling over an already saturated soil. In this case, the maximum flow on the Siret was $3,189 \mathrm{~m}^{3} / \mathrm{s}$ (19 May 1970).

The most spectacular high flood occurred between $28^{\text {th }}$ and $29^{\text {th }}$ of July, 1991, in the Tazlau river basin, resulting in the breaking up of Belci dam. In this case, in Lucacesti hydrometric station $\left(\mathrm{F}=123 \mathrm{~km}^{2}\right)$ the maximum flow had the value of $460 \mathrm{~m}^{3} / \mathrm{s}$, and in Helegiu station $\left(\mathrm{F}=984 \mathrm{~km}^{2}\right)$, it was as high as $1500 \mathrm{~m}^{3} / \mathrm{s}$. When Belci Lake was set up, the useful volume was 12.5 million $\mathrm{m}^{3}$. At the date of the accident, the useful volume was only 2 million $\mathrm{m}^{3}$, because the lake was $80 \%$ silted. The high flood on the Tazlau was included in the theoretic exceeding probability of $0.8-1 \%$. On several smaller tributaries, the high floods were appreciated with the exceeding probability of $0.1-1 \%$.

Many rivers with small dimensions had significant flows resulting in devastating local floods (table 1). During these floods, only Bacau county registered 97 casualties, destruction of 806 households, damaging of 4,377 houses, deterioration of 68 bridges and small bridges and destruction of about $20 \mathrm{~km}$ local roads. A number of 15 electric networks and 10 phone networks were interrupted, 25 facilities for clearing the torrents were damaged, as well as about $8 \mathrm{~km}$ banks defence systems. A number of 4,603 large animals and 5,732 birds died, over 4,860 ha of crops were destroyed and 6,900 ha were affected.

We have to mention the fact that the Tazlau River, situated in the SubCarpathian area, does not have a large floodplain, and therefore, the wetlands are absent or are very few. Such a water volume could not be taken by other facility and as a result, the dam was broken, despite of the efforts to stabilize it.

In the summer of 2005 the highest liquid flow was recorded on the Siret, with a value of $4,650 \mathrm{~m}^{3} / \mathrm{s}$ at Lungoci hydrometric station, situated close to the river mouth (fig. 2). We have to mention the fact that this flow is the highest of all 
interior rivers of Romania. By reconstituting the flows in the sectors where there are no hydrometric stations, we concluded that flow in the sector Cosmesti, reached about $5,000-5,500 \mathrm{~m}^{3} / \mathrm{s}$.

Table 1: Maximum flows recorded on several small rivers in the period of high floods in July 1991.

\begin{tabular}{|c|c|c|c|}
\hline No. & River & $\begin{array}{c}\mathrm{F} \\
\mathrm{km}^{2}\end{array}$ & $\begin{array}{c}\mathrm{Q}_{\max } \\
\mathrm{m}^{3} / \mathrm{s}\end{array}$ \\
\hline 1 & Strâmba & 21 & 194 \\
\hline 2 & Helegiu & 27 & 273 \\
\hline 3 & Bârsanesti & 22 & 150 \\
\hline 4 & Bratila & 13,2 & 206 \\
\hline 5 & Moreni & 52 & 275 \\
\hline 6 & Valea Rea & 11 & 145 \\
\hline 7 & Cernu & 63 & 537 \\
\hline
\end{tabular}

Lungoci hydrological station is situated next to the river mouth and represents the standard for the flows recorded on the Siret. The average multi-annual flow at Lungoci station is $210 \mathrm{~m}^{3} / \mathrm{s}$ and the average flow in July is $256 \mathrm{~m}^{3} / \mathrm{s}$ (Romanescu [11]).

A series of natural and human factors had a clear contribution to the producing of these floods. Among the natural factors, we can mention: rainfall with torrential character, prior soil humidity, high slope, and rocks which do not permit infiltration etc.; in the category of the human induced factors, we can mention the high deforestation degree, especially in the small river basins, the hydro-technical works which are non-calibrated to the high solid transport specific to the mountain areas, the poor maintenance of the floodplains, the overload of the floodplains with wrongly placed buildings etc.

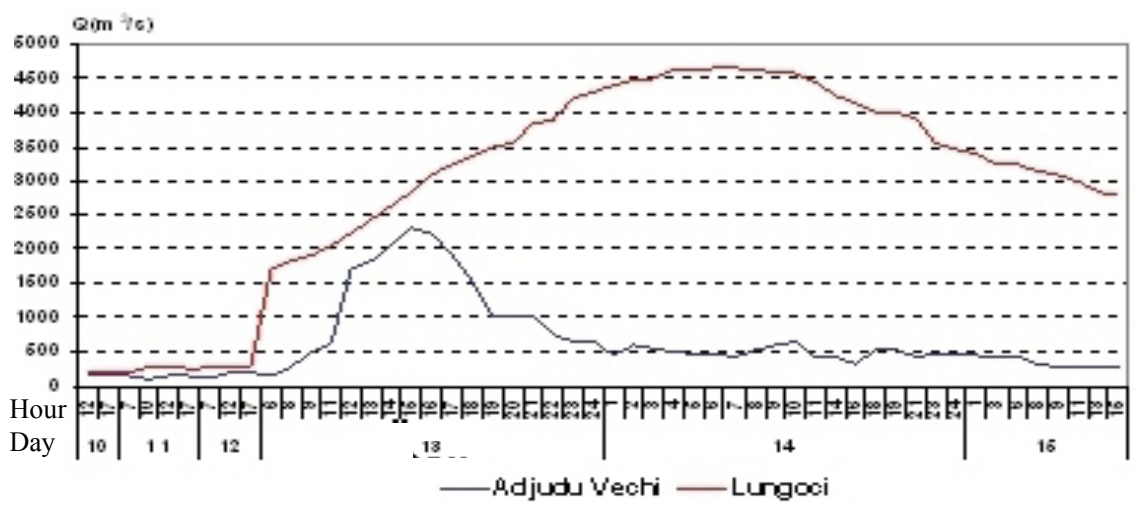

Figure 2: Hydrograph of the high flood on the Siret, in the period $10-25^{\text {th }}$ July 2005. 
The synoptic situations in the period $10-14^{\text {th }}$ July 2005 shows, on the territory of Romania, at soil level, the contact between the Azores anticyclone, occupying Central Europe, and the depression area in the south-east Europe. Over the Balkan Peninsula, a well organized depression nucleus was formed, exceeding the level of 500 hecto-pascal. This nucleus got tropical air, which was contacting the Atlantic mass, and, due to its long duration, of over 48 hours, it produced very high amounts of precipitation. The areas which were mostly affected by rainfall were situated in the middle and inferior river basin of the Bistrita (Bistricioara, Schit, Bicaz, Tarcau, Cuejd, Cracau, Nechit, Trebes sub-basins), the river basins of Trotus (including Tazlau), Susita, Putna, Râmnicul Sarat, Buzau, etc. (Siret Waters Headquarters, Bacau [20]).

The amount of precipitation fallen in the first decade of the month of July was quite rich, representing $30-50 \%$ of the average value of this month. Here and there, such amounts of precipitation generated high floods, and floods on several small water courses (Voronet, Sucevita), but also on the abrupt and deforested slopes. We can notice that on $10^{\text {th }}$ July 2005 , the precipitations were generalized in the sub-basins of Bistrita and Trotus. These precipitation fallen almost daily, maintained relatively high flows on the water courses, with values exceeding the multi-annual average monthly values (sometimes twice more), except the area of Vrancea. The precipitation responsible for the catastrophic floods in the second part of the month of July 2005 were cause, in the first place, by the showers of rains in the whole Siret river basin in the period $11^{\text {th }}-14^{\text {th }}$ July 2005 .

If in the upper sector of the Siret river basin (on the Siret river course upstream its confluence with the Bistrita River and in the Suceava, Somuz, Moldova and upper Bistrita river sub-basins), precipitation exceeded 30-401/ $\mathrm{m}^{2}$ only exceptionally, in its middle and inferior sector, precipitation had very high values. The higher precipitation fallen in Nicolae Balcescu - Roman $\left(78.6 \mathrm{l} / \mathrm{m}^{2}\right)$ and Leghin, on the Ozana river $\left(127.6 \mathrm{l} / \mathrm{m}^{2}\right)$ were not relevant, as they had an isolated character, and these areas had, on an average, much lower precipitation.

On the other hand, in the central-western sector and in the south-western sector of the Siret river basin, the high amounts of precipitation of over $100 \mathrm{l} / \mathrm{m}^{2}$ (sometimes over $200 \mathrm{l} / \mathrm{m}^{2}$ ) were generalized and they produced important high floods on the water courses in these areas.

The majority of the monitoring hydrometric station recorded values exceeding the protection quotas, and in some cases, the high floods had a catastrophic character.

The total area affected by floods was of 58,323 ha, divided into the following land use: 34,142 ha $(58.54 \%)$ arable land; 6,697 ha $(11.48 \%)$ pastures and hay fields; 1,863 ha $(3.20 \%)$ vines and orchards; 2,866 ha $(4.91 \%)$ built up area; 4,915 ha $(8.43 \%)$ forest vegetation; 2,081 ha $(3.57 \%)$ waters; 5,757 ha $(9.87 \%)$ non-productive land.

The material loss was significant, including the destruction of 10,000 households, the death of tens of thousands of animals, poultry in general, cattle and sheep. The total material loss was estimated at over 2 million Euro. Unfortunately, 24 people died as well, especially old people, and thousands of 
people were left with no house in the counties of Galati, Vrancea, Bacau and Braila.

The recorded precipitation determined flow increase and exceed of the defence quotas, causing floods which created damages in 27 localities in the county of Bacau: Dofteana, Oituz, Solont, Palanca, Brusturoasa, Agas, Darmanesti, Slanic Moldova, Asau, Comanesti, Zemes, Gura Vaii, Blagesti, Caiuti, Târgu Trotus, Urechesti, Helegiu, Poduri, Gârleni, Margineni, Moinesti, Onesti, Târgu Ocna, Casin, Buciumeni, Livezi and Bacau.

The floods affected 2,460 houses (116 being completely destroyed), 108 attached buildings, 921 ha of agricultural land, 31 bridges, 11 small bridges, 5 socio-economic objectives, $37.1 \mathrm{~km}$ of commune roads, $1.37 \mathrm{~km}$ of county roads, $0.3 \mathrm{~km}$ of national roads, $10 \mathrm{~m}$ of railways and $310 \mathrm{~m}$ of defence works. At the same time, 1,060 people were evacuated, and 56 localities remained without electricity.

The map representing the distribution of the main reservoirs and the wetlands reveals the role they have in the diminishing of the negative effects caused by the floods of the greatest internal river of Romania. At the same time, the analysis of the most catastrophic flood on the internal rivers of Romania (June 2005) emphasizes the fact that the present wetlands must be preserved and other reservoirs have to be built.

There have been marked, on an original map with the distribution of the locations which are vulnerable at hydrological risk, the most important areas which risk to be flooded by rivers which burst their banks (because of heavy rain). It is urgent for the hydrotechnical work, which is to be done, to begin at once, because the destructive phenomena are more and more frequent, and the results are extremely damaging.

\section{Discussion}

As a result of the fact that most of the rivers in the Siret river basin have significant dimensions, with large flood plains, the areas with potential floods also occupy large spaces.

Although the Siret river basin has a great number of accumulation lakes situated in the related basins or on its main course, the high flows recorded in July 2005 could not be stopped by these lakes (within Siret Waters Headquarters there are $249.63 \mathrm{~km}$ dams, $321.59 \mathrm{~km}$ regularizations, $104.15 \mathrm{~km}$ bank defence (consolidate), 8 permanent accumulations (Poiana Uzului, Bucecea, Rogojesti, Dragomirna, Somuz II, Solca, Lac Bacau, Serbauti), 3 non-permanent accumulations (Horodnic 1,2 and 3), 4 plug barrages (Mihoveni, Pascani, Trotus, Calimanesti) and 7 pumping stations. The great amount of waters flew into the mountain river basins, especially the small ones, strongly deforested. We have to mention the fact that the tree cutting accelerated after 1990, when the phenomenon of qualifies theft stopped being controlled. By cumulating, the flows increased towards the river mouths and in the accumulations with retention role important amounts of water were gathered. This water has to be evacuated when needed. In order to reduce the already existent liquid flow at attention or 
danger quotas, an intentional breaking up of dams was performed, in order to deviate part of the surplus. In this case, the flooded areas were much more extended but the damages downstream were diminished.

Even if it is not a frequent practice, the intentional breaking up of the dams during the floods in the summer of 2005, was fortuitous as the effect of the overflows would have been catastrophic to many human settlements situated in the Siret inferior sector. According to the calculations, if flooding had not been done over certain dammed surfaces, the maximum flow downstream of Cosmesti would have reached about $6,600 \mathrm{~m}^{3} / \mathrm{s}$. The flooding of the old wetlands caused the decrease of the flow to values of maximum $5,000-5,500 \mathrm{~m}^{3} / \mathrm{s}$.

Besides the material loss with negative impact on local and even national economy, we can mention the geomorphologic and soil changes: the appearance of several river islands and disappearance of other ones, the extending of several scrolls and of the concave banks by development of the bank escarpment, the enlargement of the valley lines, the changes in the water courses as a result of the self-caption by overflowing, re-flooding of several deserted meanders, the sedimentation of the polders and the appearance of new, young soils etc.

The majority of the rural settlements, and quite seldom the urban ones, are placed in floodplains and in the places where overflowing waters activate. The lack of a national program for a complete planning of the river basins, especially the maps with hydrologic and geomorphologic risk, caused a difficult management of the extreme hydrologic phenomenon. In this case, many human settlements have been affected partially or even totally (Vadu Rosca).

Such phenomena, especially in the countries with projects within programmes for the territorial planning, can represent a new start, a "Marshal" plan of the modern times. In order to avoid the future material and human loss, the attitude towards building anything and anywhere should be reconsidered. The placement of the future localities should consider only the territories which are not subject to hydrologic or geomorphologic risk.

Lockheed Martin LMT from SUA will develop, according to an agreement with Romania signed in Washington, an advanced system of hydrologic prognoses for the diminution of the effects of severe floods occurring on the territory of Romania every year. The programme called „Destructive Waters” or DESWAT represents an initiative of the Romanian Ministry of the Environment and Water Management, aiming at the consolidating the flood monitoring capacity, as well as at improving the flood modelling and prognosis capacity. Lockheed will install a number of over 600 hydrologic stations with sensors, in 11 river basins all over Romania, including the Siret river basin. The hydrologic data resulted from the sensors, together with the meteorological information given by SIMIN Radars, will be transmitted to the National Office for Hydrologic Services in Bucharest, in order to be analysed in DESWAT hydrologic models. This service has as its main task the identification of the phenomena which could turn into floods, the warning and alert on them and transmitting them to the authorities responsible with the defence against floods.

The catastrophic floods in 2005 were amplified in the strangulation points of the water courses. In order to improve the situation, the following measures need 
to be taken: optimum equipment of the bridge profile, quay planning for the enlargement of the water courses in the points where maximum flows and levels were reached, optimum deepening of the water courses in the critical points from the point of view of maximum flows and levels, creating secondary channels for the evacuation of excess water, maintenance of "dead arms" in the river flood plain, ensuring a permanent control on the evolution of the water level (alternate or conjugated opening or closing of the attached buildings along the water courses, the elimination of the buildings built up in the flood plain etc.

In the case of Siret, along the sector between Adjud (from the confluence with the Trotus) and Calimanesti, the attenuation degree is higher. The river bed supports floods between 1,400-1,600 $\mathrm{m}^{3} / \mathrm{s}$ (evaluated at Beresti accumulation), and $4,000 \mathrm{~m}^{3} / \mathrm{s}$, which indicated a diminution of the maximum values caused by the filling up of the river bed at new levels.

On the basis of the calculations regarding the advancement of the maximum flows, we can state that the diminution of the edge of the high flood on the Siret river, on the sector between the confluence with the Trotus river and Calimanesti reservoir, is about 5\%. We considered the maximum flows with exceeding probability of $1 \%$ on the Siret river, determined at the main confluences (with the Trotus, Zabrauti, Susita). We did not apply corrections for the diminishing of the maximum flows on the Siret and Trotus.

In order to balance the levels in Calimanesti accumulation, flows up to 4000 $\mathrm{m}^{3} / \mathrm{s}$ were evacuated, according to the data provided by S.C. HIDROELECTRICA - PIATRA NEAMT.

The reconstitution calculations that were done downstream of Calimanesti, in Cosmesti and Movileni sections, show that the maximum flows in this sector range between $5,000-5,500 \mathrm{~m}^{3} / \mathrm{s}$, at the exit from Calimanesti accumulation, the lateral contribution being added (Zabrauti, Susita, etc.).

The very high flows cause destruction of the dams in the weaker sectors, the overflow of waters and floods, and at Lungoci monitoring section, situated downstream the confluence with the Barlad and Putna rivers, the maximum flow did not exceed $4,650 \mathrm{~m}^{3} / \mathrm{s}$. In Lungoci section, only the flow remaining after the overflows along the Calimanesti-Lungoci sector were monitored.

For a more detailed analysis of these phenomena in determining the actual maximum flows on the Siret river downstream Calimanesti barrage and separating the natural flow from the artificial flow, very laborious calculations are necessary and new field measurements.

Unfortunately, downstream the confluence with the Trotus, on the Siret river the monitoring of the flows is only made in Lungoci section. At the existent hydrometric stations (Cosmesti and Sendreni) only observations on the levels are made, and these sections do not have limnimetric keys to offer an operative working background.

For Cosmesti section, a limnimetric key was realized by calculation. According to this key, the maximum flow evacuated from Calimanesti accumulation would be of $4,500 \mathrm{~m}^{3} / \mathrm{s}$, if the lateral contribution were decreased. For Sendreni section, the works are complicated by the presence of the remuu phenomena at the confluence with the Danube. 
On a general level, the following measures were to be immediately taken after the floods in the summer of 2005: realization of "polder" type dams, especially in the flood plains of the great water courses (fig. 3); forestation of large areas in the proper river basins or even in the flood plains of the great rivers; the planning of the agricultural terraces and of the grassy stripes on the slopes of the main river basins; regularization of the water courses by the creation of basins destined to take the water surplus; re-opening of the dams and re-ecologization of the old wetlands, desiccated at present, especially those in the great flood plains; the building up of new reservoirs, especially in the severely deforested river basins etc.

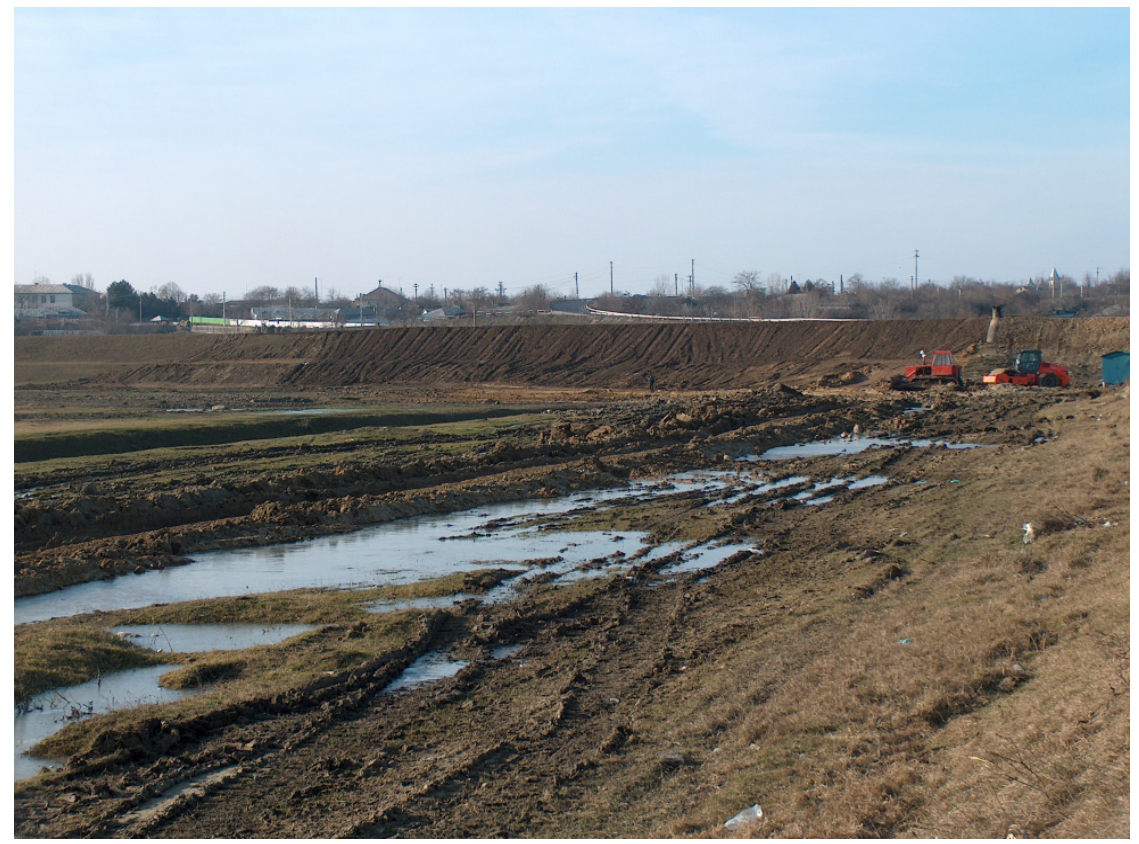

Figure 3: The dammed enclosure on the "polder" system next to Branistea.

The measures taken in order to diminish the floods do not seem to be sufficient, as the negative devastating effects of the floods that followed were quite severe, especially in the summer of 2008.

\section{Conclusions}

From the point of view of the hydro-technical works, the Siret river basin is the best equipped of the Romanian rivers. As a result of the massive deforestation during the last 18 years, many of the small river basins in the mountain sector had registered frequent floods, many of them with catastrophic effect. From this point of view, a new orientation in the river facilities system is required. 
Although the Siret river basin has a high number of reservoirs situated in the connected basins or along the main course, the high water flows recorded in July 2005 could not be stopped by them. The greatest water amounts flew in the mountain river basins, especially in the small ones, strongly deforested. We have to mention the fact that the tree cutting increased after 1990, when the phenomenon of qualified theft could not be totally controlled any more. As a result, the water flows increased towards the river mouths and, in the accumulations with retention role, important water amounts were gathered. These amounts were evacuated when needed. In order to reduce the already existent liquid flow to the attention or danger level, sometimes the controlled breaking of the dams was necessary in order to deviate a part of the excess. In this case, the flooded areas were larger, but the damages upstream were diminished.

The fact that the greatest part of the wetlands situated along the water courses were eliminated by drying up and damming, facilitated the increase of the level in the flood plain and at the same time the erosion of the banks. Re-opening and re-ecologization of the wetlands could be an efficient measure against the negative effects produced by floods.

The case of the flood in July 2005 demonstrated the fact that the majority of the rural settlements, and quite rarely the urban settlements, are situated in flood plains or in the areas covered by overflowing waters. The lack of a national program for a complete planning of the river basins, especially the lack of hydrologic and geomorphologic risk maps, caused a wrong management of the extreme hydrological phenomenon. In this case, a great part of the settlements were affected partially or even totally.

If the deforestation in the Siret river basin continues in the next years with the same intensity, the future floods will be as devastating as those in 2005 and the economic loss will strongly affect the budget balance in Romania.

\section{Acknowledgements}

We thank to the management of the Siret Waters Headquarters Bacau, especially to Mr. Dr. Petre Olaru, who was very kind to facilitate the research using the hydrologic materials in the institution archives. We also thank to the colleagues from the Geo-Archaeology Laboratory staff that helped me with the measurements in the field and the interpretation of the satellite images.

\section{References}

[1] Atlas of Waters Survey, Romania, Editura I.N.M.H., Bucuresti, 1992.

[2] André, P., Delisle, C.E. \& Revéret, J.P., L'Evaluation des impacts sur l'environnement, Presses Internationales Polytechnique, Québec, Canada, pp. 1-519, 2003.

[3] Diaconu, S., Cursuri de apa. Amenajare, Impact, Reabilitare, Editura HGA, Bucuresti, 1999. 
[4] Fustec, E. \& Frochot, B., Les functions et valeurs des zones humides, Laboratoire de Géologie appliquée-Paris VI, Laboratoire d'Ecologie-Dijon, Agence de l'Eau Seine-Normandie, pp. 1-134, 1996.

[5] Gopal, B., Turner, R.E., Wetzel, R.C. \& Whigham, D.F., Wetlands Ecology and management, In: Proceedings of the First International Wetlands Conference, September 10-17, 1980, New Delhi, India: Jaipur, India, National Institute of Ecology and International Scientific Publications, 1982.

[6] Hauer, F.R. \& Smith, R.D., The hydrogeomorphic approach to functional assessment of riparian wetlands: Evaluating impacts and mitigation on river floodplains in the U.S.A., Freshwater Biology, 40, pp. 517-530, 1998.

[7] Kentula, M.E., Restoration, Creation and Recovery of Wetlands. Wetland Restoration and Creation, In: National Water Summary on Wetland Resources, United States Geological Survey, Water-Supply Paper 2425, Washington D.C., 1996.

[8] Kolva, J.R., Restoration, Creation and recovery of Wetlands. Effect of the Great Midwest Flood of 1993 on Wetlands, In: National Water Summary on Wetland Resources, United States Geological Survey, Water-Supply Paper 2425, Washington D.C., 1996.

[9] Mustatea, A., Viituri exceptionale pe teritoriul României, Editura Institutului National de Hidrologie si Gospodarirea Apelor, Bucuresti, pp. 1-409, 2005.

[10] Romanescu, Gh., Inundatiile - intre natural si accidental, In: Riscuri si catastrofe, Editor Victor Sorocovschi, Editura Casa Cartii de Stiinta, ClujNapoca, pp. 130-138, 2003.

[11] Romanescu, Gh., Inundatiile ca factor de risc. Studiu de caz pentru viiturile Siretului din iulie 2005, Editura Terra Nostra, Iasi, pp. 1-88, 2006.

[12] Romanescu, Gh., Romanescu, G., Minea, I., Ursu, A., Margarint, M.C. \& Stoleriu C.C., Inventarierea si tipologia zonelor umede din Podisul Moldovei. Studiu de caz pentru judetele Iasi si Botosani, Editura Didactica si Pedagogica, Bucuresti, pp. 1-165, 2005.

[13] Romanescu, Gh., Romanescu, G., Stoleriu, C.C. \& Ursu A., Inventarierea si tipologia zonelor umede si apelor adânci din Podisul Moldovei, Editura Terra Nostra, Iasi, pp. 1-244, 2008.

[14] Romanescu, Gh. \& Romanescu G., Inventarierea si tipologia zonelor umede si apelor adânci din grupa nordica a Carpatilor Orientali, Editura Terra Nostra, Iasi, pp. 1-200, 2008.

[15] Skinner, J. \& Zalewski, S., Fonctions et valeurs des zones humides méditeranéennes, Conservation des zones humides méditeranéens, Skiner J., Crivelli A.J. (eds), MedWet-Tour du Valat, 2, 1996.

[16] Smith, R.D., Hydrogeomorphic approach to assessing wetland functions: Guidelines for developing Regional Guidebooks, Chapter 3: Developing a reference wetland system, ERDC/EL TR-01-29, US Army Engineer Research and Development Center, Vicksburg, MS, 2001.

[17] Selarescu, M. \& Podani, M., Apararea impotriva inundatiilor, Editura Tehnica, Bucuresti, pp.1-244, 1993. 
[18] Serban, P. \& Galie, A., Managementul apelor. Principii si reglementari europene, Editura Tipored, Bucuresti, pp. 1-304, 2006.

[19] Vasenciuc, F., Riscuri climatice generate de precipitatii in bazinul hidrografic al Siretului, Bucuresti, pp. 1-122, 2003.

[20] Siret Waters Headquarters, Bacau, Date inedited, Bacau, 2008. 